\title{
Chloramphenicol resistance in Streptomyces: cloning and characterization of a chloramphenicol hydrolase gene from Streptomyces venezuelae
}

\author{
Roy H. Mosher, ${ }^{1}$ Neelima P. Ranade, ${ }^{1}$ Hildgund SĆHrempF ${ }^{2}$ and Leo C. Vining ${ }^{1 *}$ \\ ${ }^{1}$ Department of Biology, Dalhousie University, Halifax, Nova Scotia B3H 4J1, Canada \\ ${ }^{2}$ Institut für Genetik und Mikrobiologie der Universität München, D8000 Munich 19, FRG
}

(Received 4 September 1989; accepted 30 October 1989)

\begin{abstract}
A 6.5 kb DNA fragment containing a chloramphenicol-resistance gene of Streptomyces venezuelae ISP5230 was cloned in Streptomyces lividans M252 using the high-copy-number plasmid vector pIJ702. The gene was located within a $2.4 \mathrm{~kb} \mathrm{KpnI-SstI} \mathrm{fragment} \mathrm{of} \mathrm{the} \mathrm{cloned} \mathrm{DNA} \mathrm{and} \mathrm{encoded} \mathrm{an} \mathrm{enzyme} \mathrm{(chloramphenicol} \mathrm{hydrolase)} \mathrm{that}$ catalysed removal of the dichloroacetyl moiety from the antibiotic. The deacylated product, $p$-nitrophenylserinol, was metabolized to p-nitrobenzyl alcohol and other compounds by enzymes present in S. lividans M252. Examination of the genomic DNA from several sources using the cloned $6.5 \mathrm{~kb}$ SstI fragment from $S$. venezuelae ISP5230 as a probe showed a hybridizing region in the DNA from $S$. venezuelae 13s but none in the DNA from another chloramphenicol producer, Streptomyces phaeochromogenes NRRLB 3559. The resistance phenotype was not expressed when the $6.5 \mathrm{~kb}$ SstI fragment or a subfragment was subcloned behind the lac-promoter of plasmid pTZ18R in Escherichia coli.
\end{abstract}

\section{Introduction}

Chloramphenicol resistance in many Gram-positive and Gram-negative bacteria is mediated by the enzyme chloramphenicol acetyltransferase (CAT; EC 2.3.1.28) which inactivates the antibiotic by catalysing its $O$ acetylation (Shaw, 1975). However, CAT activity could not be detected in the chloramphenicol-producing actinomycete Streptomyces venezuelae (Shaw \& Hopwood, 1976) and does not appear to have a role in protecting this organism from the toxic product of its own metabolism (Vining \& Westlake, 1984). Chloramphenicol is bacteriostatic and acts primarily by inhibiting protein synthesis (Pongs, 1979). It binds to prokaryotic ribosomes, including those of $S$. venezuelae. In vitro protein synthesizing systems derived from chloramphenicol-producing or non-producing mycelia are equally sensitive (Malik \& Vining, 1972). Non-producing cultures exposed to chloramphenicol are initially inhibited but grow after a lag that varies with the drug concentration. The bacteria are then resistant to chloramphenicol at the concentration to which they were exposed, but are returned to the sensitive state by one passage through unsupplemented medium (Vining \& Westlake, 1984).

Abbreviation: CAT, chloramphenicol acetyltransferase.
$S$. venezuelae possesses an intracellular enzyme that inactivates chloramphenicol by removing the dichloroacetyl substituent (Malik \& Vining, 1971). Since this chloramphenicol hydrolase was found in comparable amounts in producing or non-producing cultures, it was presumed not to be responsible for the inducible characteristics of resistance in $S$. venezuelae. To account for inducibility, Malik \& Vining $(1970,1972)$ suggested that the mycelium becomes less permeable to chloramphenicol after exposure to exogenous antibiotic; the activity of chloramphenicol hydrolase might then reduce the intracellular concentration. To clarify the mechanisms by which $S$. venezuelae is resistant to its own antibiotic, we have cloned a fragment of $S$. venezuelae genomic DNA conferring chloramphenicol resistance in a heterologous host, Streptomyces lividans M252. Some features of this resistance are described.

\section{Methods}

Bacterial strains and plasmids. The sources and characteristics of these are described in Table 1.

Chemicals and enzymes. Lysozyme, phage $\lambda$ DNA, restriction endonucleases and T4 DNA ligase were purchased from Boehringer Mannheim or BRL. Ultrapure agarose was obtained from Bio-Rad Laboratories. Chloramphenicol, ampicillin and 1,3-diacetoxychloramphenicol were purchased from Sigma; 1,3-diacetoxychloramphenicol 
Table 1. Bacterial strains and plasmids

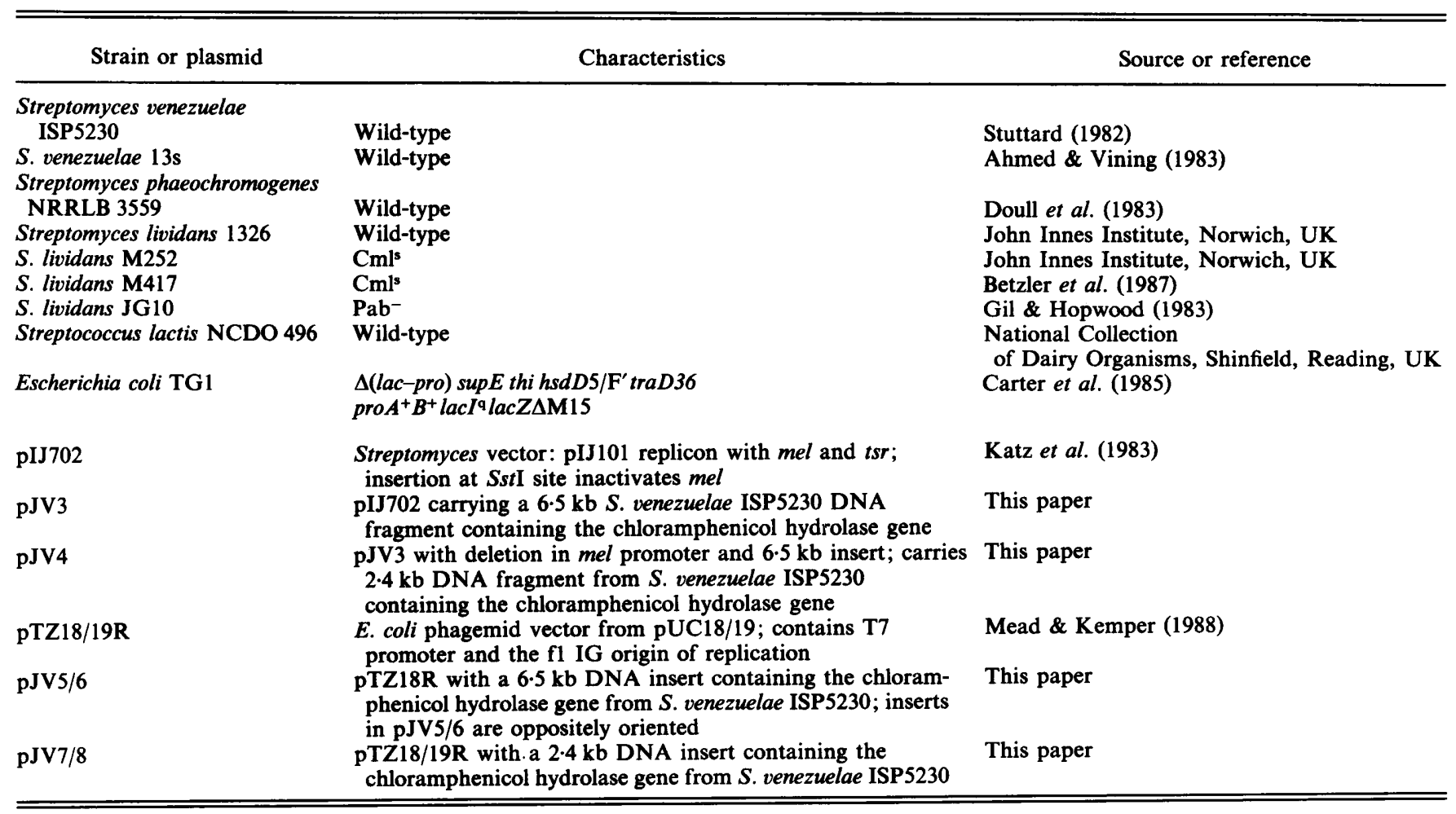

was purified by TLC and recrystallization. Both p-nitrobenzoic acid and $p$-nitrobenzyl alcohol were purchased from Kodak. $N$-Acetyl- $p$ nitrophenylserinol was a gift from Parke-Davis. Thiostrepton was a gift from S. J. Lucania, E. R. Squibb \& Sons, New Brunswick, NJ, USA.

$\left[\mathrm{U}-{ }^{14} \mathrm{C}\right] \mathrm{Chloramphenicol}$ was labelled biosynthetically from [U${ }^{14} \mathrm{Clglucose}$ (Malik \& Vining, 1970); p-nitrophenyl[hydroxymethylene$\left.{ }^{14} \mathrm{C}\right]$ serinol was prepared by hydrolysis of [hydroxymethylene- $\left.{ }^{14} \mathrm{C}\right] \mathrm{chlor}-$ amphenicol (Rebstock et al., 1949) purchased from Amersham.

Media and culture conditions. Streptomyces venezuelae ISP5230 was maintained on MYM medium as described by Doull et al. (1985). Streptomyces lividans strains were maintained on R5(-S) medium which consisted of R5 regeneration medium (Hopwood et al., 1985) without sucrose. For plating $S$. lividans 3131 harbouring pIJ702, thiostrepton $\left(30 \mu \mathrm{g} \mathrm{ml}^{-1}\right)$ was included in R5( $\left.-\mathrm{S}\right)$ medium. Minimal medium was as described by Hopwood (1967). Streptomyces cultures were grown at $30^{\circ} \mathrm{C}$ until sporulation (4-5 d). Spores were harvested and stored as suspensions in $20 \%(\mathrm{v} / \mathrm{v})$ glycerol at $-20^{\circ} \mathrm{C}$ (Hopwood et al., 1985).

Cultures of streptomycetes grown in liquid media were incubated at $30{ }^{\circ} \mathrm{C}$ on a rotary shaker $(220$ r.p.m.; $3.7 \mathrm{~cm}$ eccentricity). Mycelium used for protoplast formation was from cultures $(25 \mathrm{ml}$ per $250 \mathrm{ml}$ Erlenmeyer flask) grown for $36-40 \mathrm{~h}$ in YEME medium (Hopwood et al., 1985) supplemented with $34 \%$ (w/v) sucrose, $5 \mathrm{~mm}-\mathrm{MgCl}_{2}$, and $0.5 \%(\mathrm{w} / \mathrm{v})$ glycine. For assessing chloramphenicol resistance, cultures $(50 \mathrm{ml}$ per $500 \mathrm{ml}$ Erlenmeyer flask) were grown in YEME or tryptic soy (TS) medium [sucrose, $10 \%(w / v)$; tryptic soy broth, 3\% (w/v); $\mathrm{MgCl}_{2} \cdot 6 \mathrm{H}_{2} \mathrm{O}, 1 \%(\mathrm{w} / \mathrm{v})$; yeast extract, $1 \%(\mathrm{w} / \mathrm{v})$; and supplemented after autoclaving with $\mathrm{CaCl}_{2}$ to $1.5 \mathrm{mg} \mathrm{ml}^{-1}$ ]. For metabolite isolation, cultures ( $100 \mathrm{ml}$ per $500 \mathrm{ml}$ Erlenmeyer flask) were grown in GNY medium (Malik \& Vining 1970).
Cultures used for plasmid isolation or for vegetative inocula were initiated with spores harvested from agar plate cultures. Unless stated otherwise, vegetative inocula were grown for $48 \mathrm{~h}$ and added in amounts of $1 \%(\mathrm{v} / \mathrm{v})$ to initiate cultures used to assess resistance, or $5 \%$ $(v / v)$ to cultures used for metabolite isolation.

Cultures of E. coli on agar media were grown at $37^{\circ} \mathrm{C}$ for $24 \mathrm{~h}$. Shaken cultures $(50 \mathrm{ml}$ per $250 \mathrm{ml}$ Erlenmeyer flask) used in plasmid isolation or to prepare competent cells were inoculated with 10-20 colonies and grown overnight at $37^{\circ} \mathrm{C}$ in L-broth (Hopwood et al., 1985). Cultures of $E$. coli TGl harbouring $\mathrm{pTZ18} / 19 \mathrm{R}$ were grown on $\mathrm{L}$-agar or in L-broth containing $50 \mu \mathrm{g}$ ampicillin $\mathrm{ml}^{-1}$.

Plasmid and genomic DNA. Plasmid DNA from Streptomyces or E. coli was isolated by the rapid alkaline lysis method of Kieser (1984); for larger amounts the procedure was scaled up 10-fold and was followed by $\mathrm{CsCl}$-ethidium bromide density gradient centrifugation. Genomic DNA was isolated and purified as described previously (Schrempf, 1982).

Restriction endonuclease digestion and ligation of DNA. Genomic DNA $(10 \mu \mathrm{g})$ from $S$. venezuelae ISP5230 was digested with $S s t \mathrm{I}$ under conditions (Thompson et al., 1982) that gave fragments predominantly $1-15 \mathrm{~kb}$ in size. The digest was combined with an Sst digest of pIJ702 $(2 \mu \mathrm{g})$, heated to $65^{\circ} \mathrm{C}$ for $10 \mathrm{~min}$, placed on ice for $5 \mathrm{~min}$ and diluted with 2 vols absolute ethanol. After two washes with $70 \%$ (v/v) ethanol, the precipitated DNA was dissolved in ligation buffer $(20 \mathrm{mM}-\mathrm{Tris} / \mathrm{HCl}$ pH 7.6, $10 \mathrm{~mm}-\mathrm{MgCl}_{2}, 10 \mathrm{~mm}$-dithioerythritol, $0.6 \mathrm{mM}$-ATP) at a DNA concentration of $40 \mu \mathrm{g} \mathrm{ml}^{-1}$. The solution was incubated for $12-16 \mathrm{~h}$ at $14^{\circ} \mathrm{C}$ with 1 unit of T4-DNA ligase, ligation being monitored by electrophoresis. The DNA was precipitated with ethanol, washed once with $70 \%$ ethanol and resuspended in TE buffer. 
Protoplast transformation. Protoplasts in a small volume of P-buffer (Hopwood et al., 1985) were mixed with $20 \mu \mathrm{l}$ of ligated plasmid DNA in TE buffer (10 mM-Tris/HCl, pH 8.0, 1 mM-EDTA) and $0.5 \mathrm{ml} 25 \%$ $(\mathrm{w} / \mathrm{v})$ polyethylene glycol 1000 in T-medium. They were immediately washed with P-buffer, recovered by centrifugation and spread $(100 \mu \mathrm{l}$ per plate) on partially dried R5 agar (Thompson et al., 1982). After 18$20 \mathrm{~h}$ at $30^{\circ} \mathrm{C}$, regenerating colonies were overlaid with soft nutrient agar $(3 \mathrm{ml})$ containing enough thiostrepton to give a plate concentration of $30 \mu \mathrm{g} \mathrm{ml}^{-1}$. Transformants carrying the $t s r$ gene of $\mathrm{pIJ} 702$ were visible within 1-2 d, and the melanin excreted by those containing intact pIJ702 was evident by the third day. At this time, all thiostrepton-resistant colonies were transferred to minimal medium supplemented with 25 or $50 \mu \mathrm{g}$ chloramphenicol $\mathrm{ml}^{-1}$.

Cells of $E$. coli TG1 were made competent and were transformed as described by Hopwood et al. (1985).

DNA hybridization. Genomic DNA samples were digested with SstI. Fragments were precipitated with ethanol, electrophoresed in a $0.7 \%$ (w/v) agarose gel and transferred to a nitrocellulose hybridization filter. The recombinant plasmid pJV3 containing the $6.50 \mathrm{~kb}$ DNA insert was digested with SstI, ClaI and BamHI; since only pIJ702 DNA contains recognition sites for the latter two endonucleases, it was cleaved into fragments of $1.60,1.70$ and $2.50 \mathrm{~kb}$ which were readily separated from the $6.50 \mathrm{~kb}$ insert by electrophoresis overnight at $40 \mathrm{~V}$ in $0.6 \%(\mathrm{w} / \mathrm{v})$ ultrapure agarose gels. The $6.5 \mathrm{~kb}$ DNA fragment was eluted from the gel into TBE buffer ( $89 \mathrm{mM}$-Tris, $89 \mathrm{~mm}$-boric acid, 2 mM-EDTA); the solution was extracted with phenol/chloroform and then chloroform. The DNA was precipitated with absolute ethanol, washed with $70 \%$ ethanol and resuspended in TE buffer.

Samples of DNA were nick-translated in the presence of $[\alpha-$ $\left.{ }^{32} \mathrm{P}\right] \mathrm{dATP}$ and $\left[\alpha_{-32} \mathrm{P}\right] \mathrm{dGTP}$. Southern hybridization with SstIdigested genomic DNA was done at $70^{\circ} \mathrm{C}$ for $12 \mathrm{~h}$ as described by Hopwood et al. (1985). The membrane containing the DNA was washed four times at $70^{\circ} \mathrm{C}$ for $30 \mathrm{~min}$ with SSC $(1 \times \mathrm{SSC}$ is $0.15 \mathrm{M}$ $\mathrm{NaCl}, 0.015 \mathrm{M}$-sodium citrate, $\mathrm{pH} 7.0$ ) containing $0.1 \%$ SDS. The concentration of SSC in the first two washes was $2 \times$ and in the last two $0.2 \times$. The membrane was exposed to X-ray film (Kodak X-Omat) for $5 \mathrm{~d}$ at $-70^{\circ} \mathrm{C}$.

Analysis of cultures. Resistance to chloramphenicol and its metabolites was measured by comparing the mycelium dry weight of cultures grown in TS medium with or without the test compound at a range of concentrations. For $S$. lividans RM3 the inoculum medium was supplemented with $25 \mu \mathrm{g}$ chloramphenicol ml-1 to maintain selection for pJV3.

To identify metabolic products of chloramphenicol, cultures of $S$. lividans 1326, M252 and RM3 were supplemented with either chloramphenicol or $p$-nitrophenylserinol and harvested at $24 \mathrm{~h}$ intervals by centrifugation. In some cultures of $S$. lividans RM3, [U${ }^{14} \mathrm{C}$ ]chloramphenicol or $p$-nitrophenyl[hydroxymethylene $\left.{ }^{-14} \mathrm{C}\right]$ serinol was used as the supplement and cultures were grown for only $24 \mathrm{~h}$. For all cultures, the supernatant solution collected by centrifugation was extracted with ethyl acetate and the extract was separated into nonacid/water (12:3:5, by vol.) for aqueous fractions. Aromatic comby TLC on silica gel (Sil 60 F254; Merck) using chloroform/methanol $(9: 1, v / v)$ as the solvent system for extracts, and $n$-butanol/acetic acid/water (12:3:5 by vol.) for aqueous fractions. Aromatic compounds were visualized as fluorescence-quenching zones under light of $254 \mathrm{~nm}$. Chromatograms were scanned for radioactivity with a gasflow Geiger-Mueller detector (Packard model 7200) synchronized with a strip chart recorder. The amount of radioactivity in solutions was measured with an LKB Wallac model 1215 liquid scintillation counter.

To search for possible metabolites of chloramphenicol in $E$. coli strains transformed with plasmids $\mathrm{pJV} 7$ and $\mathrm{pJV} 8$, cultures were grown for $24 \mathrm{~h}$ in minimal medium containing chloramphenicol $\left(0.2 \mu \mathrm{g} \mathrm{ml}^{-1}\right)$ and isopropyl thiogalactoside. The broths were extracted with ethyl acetate and the extracts were concentrated and examined by TLC on silica gel with chloroform/methanol $(9: 1, v / v)$ and ethyl acetate/acetic acid/water (14:7:1, by vol.) as solvent systems. Authentic samples of chloramphenicol, $p$-nitrophenylserinol and $N$-acetyl-p-nitrophenylserinol were included as reference compounds.

Isolation of metabolites. Cultures of S. lividans 1326 and RM3 that had been supplemented with the test compound were centrifuged and the pelleted mycelium was washed with water; the pellet was then leached with acetone. The supernatant solution from the culture was extracted with ethyl acetate successively at $\mathrm{pH} 8 \cdot 5,5.0$ and 2.5 . The acetone and ethyl acetate extracts were each evaporated, redissolved in $250 \mu \mathrm{l}$ ethyl acetate and chromatographed on preparative layers of silica gel using chloroform/methanol $(9: 1, \mathrm{v} / \mathrm{v})$ as solvent. Fluorescence-quenching zones were scraped from plates; the adsorbed substances were eluted with acetone and the solutions were evaporated.

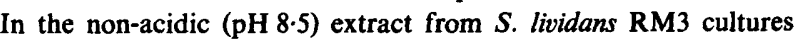
supplemented with $\left[\mathrm{U}^{-14} \mathrm{C}\right]$ chloramphenicol $\left(3 \mu \mathrm{g} \mathrm{ml}^{-1} ; 25.6 \mu \mathrm{Ci}\right.$ $\left.\mathrm{mmol}^{-1}\right)$, the residue from a zone with the same mobility $\left(R_{F} 0.72\right)$ as $p$ nitrobenzyl alcohol contained $0.89 \mathrm{nCi}$ of radioactivity. Admixture with unlabelled $p$-nitrobenzyl alcohol $(25 \mathrm{mg})$ and three recrystallizations from water gave specific activities of 5.5, 6.5 and 6.1 nCi mmol ${ }^{-1}$. A second radioactive zone in the non-acidic extract matched $N$-acetyl$p$-nitrophenylserinol $\left(R_{F} 0.34\right)$ in mobility. The eluate $(1.3 \mathrm{nCi})$ was mixed with unlabelled $N$-acetyl-p-nitrophenylserinol $(25 \mathrm{mg})$. In successive recrystallizations from water, its specific activity remained constant at $13 \cdot 2 \mathrm{nCi} \mathrm{mmol}^{-1}$. ( $(1 \mathrm{Ci}=37 \mathrm{GBq}$.)

Metabolites with $R_{F}$ values of 0.34 and 0.72 detected by TLC analysis of non-acidic extracts from $S$. lividans $M 252$ cultures supplemented with $p$-nitrophenylserinol, and from $S$. lividans RM3 cultures supplemented with p-nitrophenyl[hydroxymethylene $\left.{ }^{-14} \mathrm{C}\right]$ serinol $\left(200 \mu \mathrm{g} \mathrm{ml}^{-1} ; 1.06 \mu \mathrm{Ci} \mathrm{mmol}^{-1}\right)$, were separated by preparative TLC, eluted and crystallized from water. The substances at $\boldsymbol{R}_{\mathrm{F}} \mathbf{0 . 3 4}$ from each source were obtained as needles, m.p. $129^{\circ} \mathrm{C}$, indistinguishable in melting point, infrared and ${ }^{1} \mathrm{H}$-nuclear magnetic resonance (NMR) spectra from authentic $N$-acetyl-p-nitrophenylserinol (Doull et al., 1985). The specific activity of the product from $S$. lividans $R M 3$ was $1.01 \mu \mathrm{Ci} \mathrm{mmol}^{-1}$. The substances at $R_{F} \mathbf{0 . 7 2}$ were obtained as needles; m.p. $92{ }^{\circ} \mathrm{C}$, unchanged on admixture with authentic p-nitrobenzyl alcohol. Its identity was confirmed by comparison of infrared and ${ }^{1} \mathrm{H}-$ NMR spectra with those of $p$-nitrobenzyl alcohol.

In the non-acidic extract from $S$. lividans 1326 cultures supplemented with chloramphenicol, a zone at $\boldsymbol{R}_{\boldsymbol{F}} \mathbf{0 . 9 2}$ corresponded in mobility to 1,3-diacetoxychloramphenicol. When the product eluted from this zone was recrystallized from water, it yielded colourless needles, m.p. $141^{\circ} \mathrm{C}$ alone or after mixing with authentic 1,3-diacetoxychloramphenicol. The ${ }^{1} \mathrm{H}$-NMR spectrum, recorded in deuterochloroform at $300 \mathrm{MHz}$ on a Bruker model MSL-300 spectrometer with tetramethylsilane as the internal reference, contained signals at $\delta$ (p.p.m.) $2 \cdot 11$ (s, 3H, acetoxy $\left.\mathrm{CH}_{3}\right), 2 \cdot 19\left(\mathrm{~s}, 3 \mathrm{H}\right.$, acetoxy $\left.\mathrm{CH}_{3}\right), 4 \cdot 06\left(\mathrm{q}, 1 \mathrm{H}, \mathrm{H}-1 \mathrm{a}^{\prime}, J_{1 \mathrm{a}^{\prime}, 1 \mathrm{~b}^{\prime}} 6 \cdot 1 \mathrm{~Hz}, J_{1 \mathrm{a}^{\prime}, 2^{\prime}}\right.$ $5.6 \mathrm{~Hz}$ ), 4.19 (q, $1 \mathrm{H}, \mathrm{H}-1 \mathrm{~b}^{\prime}, J_{1 \mathrm{~b}^{\prime}, \mathrm{a}^{\prime}} 6.1 \mathrm{~Hz}, \mathrm{~J}_{1 \mathrm{~b}^{\prime}, 2^{2}} 5.6 \mathrm{~Hz}$ ), 4.61 (q, $1 \mathrm{H}, \mathrm{H}-\mathrm{z}^{\prime}$, $J_{2^{\prime}, 1 \mathrm{l}^{\prime}} 5.6 \mathrm{~Hz}, J_{2^{\prime}, 1 \mathrm{~b}^{\prime}} 5.6 \mathrm{~Hz}$ ), $4.82(\mathrm{bs}, 1 \mathrm{H}, \mathrm{NH}), 5.86\left(\mathrm{~s}, 1 \mathrm{H}, \mathrm{CHCl} \mathrm{C}_{2}\right), 6.07$ (d, $1 \mathrm{H}, H-3^{\prime}, J_{3^{\prime}, 2^{\prime}} 5.7 \mathrm{~Hz}$ ), 7.89 (AA' $\mathrm{AB}^{\prime}, 4 \mathrm{H}, H-2, H-3, H-5, H-6$, consisting of doublets at 7.53 and 8.24 p.p.m., $J_{2,3}=J_{5,6}=8.7 \mathrm{~Hz}$ ). The data were consistent with the assigned structure and matched those obtained with the authentic sample.

\section{Results}

Sensitivity of $S$. venezuelae and $S$. lividans strains to chloramphenicol

The minimum inhibitory concentration (MIC) of chloramphenicol for $S$. venezuelae ISP5230 grown on MYM medium was $200 \mu \mathrm{g} \mathrm{ml}^{-1}$. S. lividans strains 1326 
0 7 $14 \mathrm{~kb}$

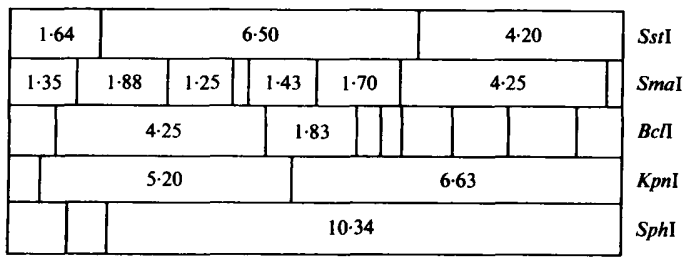

Fig. 1. Restriction map of plasmid pJV3 linearized with BamHI; sizes were determined by comparison with HindIII- and PstI-digested $\lambda$ phage DNA. The position of restriction sites in the $6.5 \mathrm{~kb}$ insert was determined by single and multiple digestions with the restriction enzymes indicated in the diagram. The position of sites in the vector region is as given by Hopwood et al. (1985).

and JG10 had an MIC of $20 \mu \mathrm{g} \mathrm{ml}^{-1}$ but strains M417 and M252, both of which had been selected for sensitivity to chloramphenicol (Betzler et al., 1987; Schottel et al., 1981), failed to grow at drug concentrations above 3 and $6 \mu \mathrm{g} \mathrm{ml}^{-1}$, respectively.

\section{Isolation and characterization of plasmid pJV3}

After complete digestion with SstI, genomic DNA from $S$. venezuelae ISP5230 contained fragments of predominantly $1-15 \mathrm{~kb}$. These were ligated to $S s t \mathrm{I}$-cleaved pIJ702 and the ligation mixture was used to transform protoplasts of $S$. lividans M252. Regeneration of the protoplasts under selective conditions yielded semi-confluent lawns of thiostrepton-resistant transformants. When these were replica-plated on minimal medium supplemented with 25 or $50 \mu \mathrm{g}$ chloramphenicol $\mathrm{ml}^{-1}$, three colonies from approximately 10000 melanin-negative transformants grew rapidly at both drug concentrations.

All three resistant transformants contained recombinant plasmids. Two of the plasmids, with inserts of 0.7 and $1.7 \mathrm{~kb}$, failed to confer chloramphenicol resistance when they were isolated and reintroduced into $S$. lividans M252. The third plasmid, from transformant RM3, contained a $6.5 \mathrm{~kb}$ insert. When this plasmid (pJV3) was used to transform $S$. lividans M252, all of the 16 thiostrepton-resistant colonies tested were also chloramphenicol resistant. With a second host, S. lividans M417, all 12 colonies selected for resistance to $50 \mu \mathrm{g}$ thiostrepton $\mathrm{ml}^{-1}$ after transformation with pJV3 were resistant to $12.5 \mu \mathrm{g}$ chloramphenicol $\mathrm{ml}^{-1}$.

Plasmid DNA from $S$. lividans RM3 was extracted by the rapid alkaline procedure of Kieser (1984) and was digested with restriction enzymes, both singly and in combination. Comparison of the fragments by agarose gel electrophoresis with those obtained from pIJ702 gave the restriction map shown in Fig. 1. To locate the region

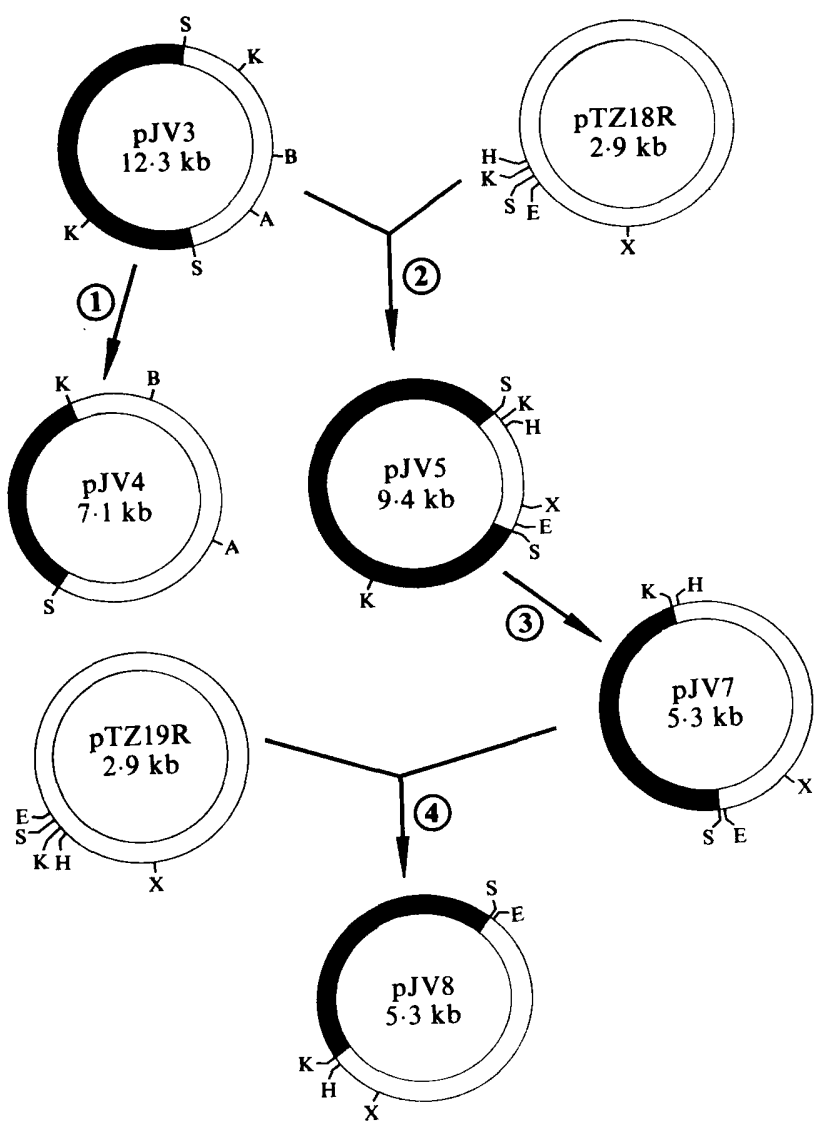

Fig. 2. Derivation of recombinant plasmids. 1.pJV3 was digested with $K p n I$ and the ligated mixture was used to transform S. lividans M252. From the transformants, a clone containing pJV4 was isolated; this had undergone a $4.1 \mathrm{~kb}$ deletion from the insert and carried the $\mathrm{cm}^{\mathrm{r}}$ determinant in a $2.4 \mathrm{~kb}$ KpnI-SstI segment of DNA. 2. pJV5 was formed by digesting both pJV3 and pTZ18R with SstI, ligating the mixture and using it to transform $E$. coli TG1; screening of the transformants yielded a clone containing pJV5. 3. pJV5 was digested with KpnI, ligated and used to transform E. coli; among the transformants was one in which the resident plasmid had undergone a $4.1 \mathrm{~kb}$ deletion to yield pJV7. 4. Digestion of pJV7 with KpnI and SstI gave a $2.4 \mathrm{~kb}$ fragment; this was ligated to pTZ19R digested with the same enzymes and the mixture used to transform $E$. coli TG1. From the transformants, a clone containing pJV8 was isolated. The diagram is not drawn to scale. A, ApaI; B, BamHI; C, ClaI ; E, EcoRI ; H, HindIII; K, KpnI; S, SstI; X, XmnI.

within the cloned fragment that conferred chloramphenicol resistance, pJV3 was digested with $K p n I$. Ligation of the products with T4-DNA ligase gave DNA that transformed $S$. lividans M252 to thiostrepton resistance. All these transformants grew on a medium containing $12.5 \mu \mathrm{g}$ chloramphenicol $\mathrm{ml}^{-1}$. Plasmid extraction afforded pJV4 in which a $5.2 \mathrm{~kb}$ fragment of pJV3 had been deleted (Fig. 2). The deleted region consisted of a $4 \cdot 1 \mathrm{~kb}$ Sst I-KpnI fragment derived from the insert, along with a $1.1 \mathrm{~kb} K p n I-S s t I$ fragment from pIJ702. This 
(a)

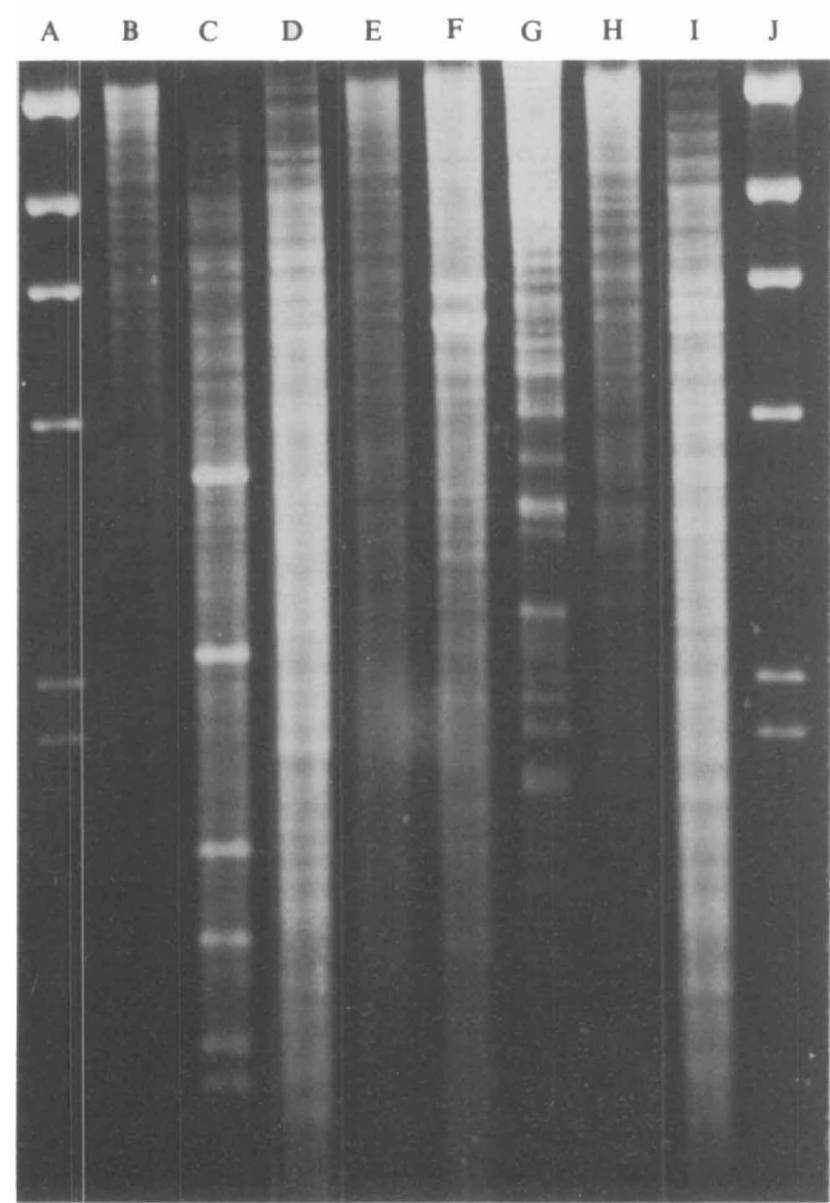

(b)

$\begin{array}{lllllllllll}\text { A } & \text { B } & \text { C } & \text { D } & \text { E } & \text { F } & \text { G } & \text { H } & \text { I } & \text { J }\end{array}$

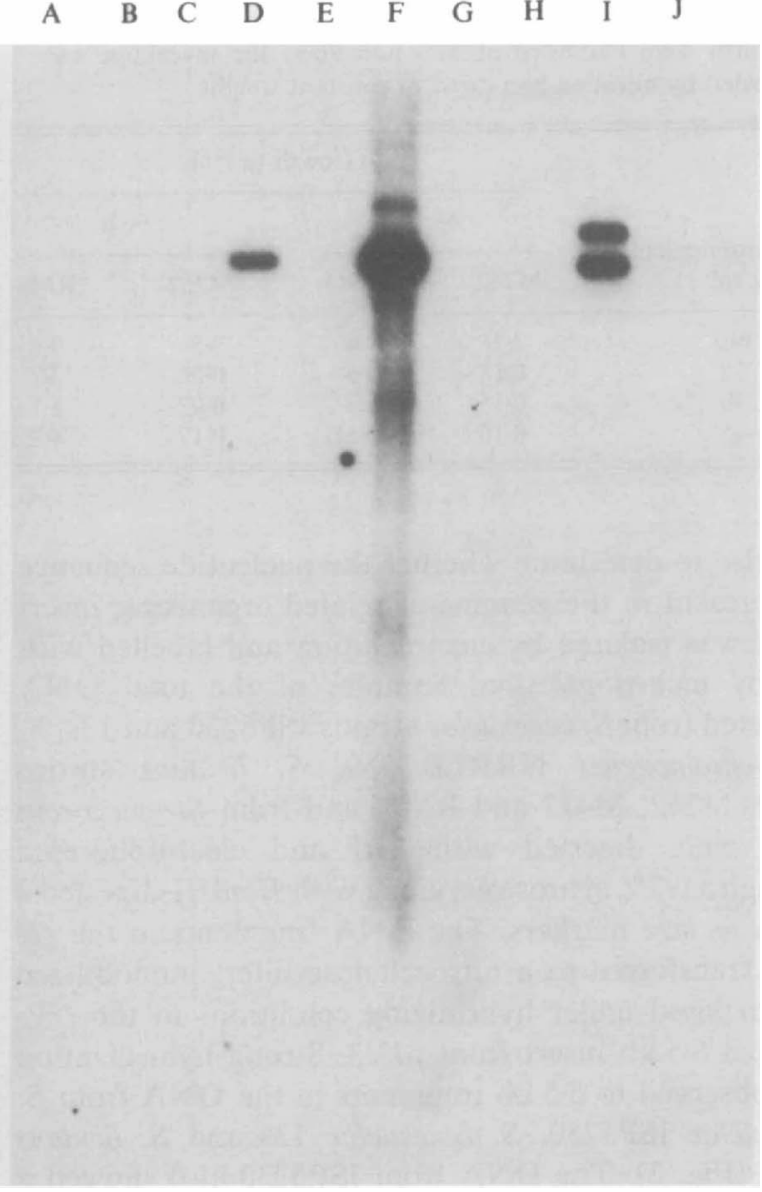

Fig. 3. Agarose gel electrophoresis $(a)$ of restriction endonuclease digests of genomic DNA samples and Southern hybridization $(b)$ with a ${ }^{32} \mathrm{P}$-labelled $6.5 \mathrm{~kb}$ Sst I DNA fragment from $S$. venezuelae ISP5230 under stringent conditions $\left(70^{\circ} \mathrm{C}\right)$. The samples are: lane A, $\lambda$; B, S. lividans JG10; C, S. phaeochromogenes; D, S. venezuelae 13s; E, S. lividans M417; F, S. lividans RM3; G, S. lactis; H, S. lividans M252; I, S. venezuelae ISP5230; J, $\lambda$. $\lambda$ DNA was digested with HindIII; all other samples were digested with SstI.

pIJ702 fragment is believed to carry the promoter region of the mel gene (Hopwood et al., 1985). Retransformation of $S$. lividans M252 with pJV4 gave thiostrepton-resistant colonies that were also chloramphenicol resistant.

The $6.5 \mathrm{~kb}$ fragment excised from pJV3 was shotguncloned into an SstI site within the polylinker sequence downstream of the lac-promoter in pTZ18R to give two recombinant plasmids, pJV5 and pJV6. From single and double digestions of pJV5 and pJV6 with SstI, KpnI and Pst $\mathrm{I}$, and electrophoretic measurement of fragment sizes against a HindIII-digested $\lambda$ DNA reference (data not shown), it was concluded that the $6.5 \mathrm{~kb}$ insert was present in opposite orientations in the two plasmids. In cultures grown with or without isopropyl thiogalactoside as an inducer, neither plasmid conferred chloramphenicol resistance on $E$. coli TG1. Subcloning the $2.4 \mathrm{~kb}$ KpnI-SstI S. venezuelae DNA fragment from pJV4 in the polylinker regions of pTZ18R and pTZ19R (vectors with the same polylinker sequence in reverse orientations to the lac promoter) gave the recombinant plasmids pJV7 and pJV8, respectively. These also failed to confer chloramphenicol resistance on $E$ : coli transformants.

To ascertain whether the chloramphenicol hydrolase gene was expressed in the $E$. coli transformants without conferring resistance to the antibiotic, cultures were grown in a sub-inhibitory concentration of chloramphenicol and extracts were examined by TLC. Whereas unchanged antibiotic could be readily located, no substances corresponding in $\boldsymbol{R}_{\boldsymbol{F}}$ value with $p$-nitrophenylserinol or $N$-acetyl-p-nitrophenylserinol were detected, even when lac expression was induced with isopropyl thiogalactoside.

\section{Southern hybridization}

To confirm that the $6.5 \mathrm{~kb}$ insert of pJV3 hybridized to a region in the genomic DNA of $S$. venezuelae ISP5230, 
Table 2. Effect of chloramphenicol on the growth of S. lividans strains M252 and RM3

Cultures were harvested at $48 \mathrm{~h}$ and $96 \mathrm{~h}$ : the mycelium was collected by filtration and dried to constant weight.

\begin{tabular}{cccccc}
\hline \hline & \multicolumn{4}{c}{ Growth (g 1-1) } \\
\cline { 2 - 4 } \cline { 5 - 6 } $\begin{array}{c}\text { Chloramphenicol } \\
\left(\mu \mathrm{g} \mathrm{ml}^{-1}\right)\end{array}$ & M252 & RM3 & & M252 & RM3 \\
\cline { 2 - 3 } \cline { 3 - 6 } Nil & 3.7 & 4.4 & 3.5 & 3.6 \\
15 & 0.18 & 2.6 & 0.06 & 3.7 \\
30 & 0.15 & 1.3 & 0.02 & 4.1 \\
45 & 0.16 & 0.51 & 0.17 & 4.2 \\
\hline \hline
\end{tabular}

and also to determine whether the nucleotide sequence was present in the genome of related organisms, insert DNA was isolated by electroelution and labelled with ${ }^{32} \mathrm{P}$ by nick-translation. Samples of the total DNA extracted from $S$. venezuelae strains ISP5230 and 13s, $S$. phaeochromogenes NRRLB 3559, $S$. lividans strains JG10, M252, M417 and RM3, and from Streptococcus lactis were digested with SstI and electrophoresed through a $0.7 \%$ agarose gel along with HindIII-digested $\lambda$ DNA as size markers. The DNA fragments in the gel were transferred to a nitrocellulose filter, immobilized and exposed under hybridizing conditions to the ${ }^{32} \mathrm{P}$ labelled $6.5 \mathrm{~kb}$ insert from pJV3. Strong hybridization was observed to $6.5 \mathrm{~kb}$ fragments in the DNA from $S$. venezuelae ISP5230, S. venezuelae $13 \mathrm{~s}$ and $S$. lividans RM3 (Fig. 3). The DNA from ISP5230 also showed a second hybridizing fragment of $8 \mathrm{~kb}$. No hybridization was detected with DNA from the other organisms.

\section{Effect of chloramphenicol on growth}

Cultures of RM3 and M252 in TS medium without antibiotic grew at the same rate and achieved a similar maximum yield after $2 \mathrm{~d}$. However, S. lividans M252 was markedly inhibited by $6 \mu \mathrm{g}$ chloramphenicol $\mathrm{ml}^{-1}$ and little growth occurred at $15 \mu \mathrm{g} \mathrm{ml}^{-1}$. In contrast, cultures of $S$. lividans RM3 containing chloramphenicol supplements of from 15 to $45 \mu \mathrm{g} \mathrm{ml}^{-1}$ showed an approximately linear decrease in growth after $2 \mathrm{~d}$ incubation (Table 2). By the fourth day, all cultures had accumulated similar amounts of biomass.

\section{Chloramphenicol metabolism by S. lividans RM3}

To determine whether the antibiotic was metabolized, cultures of $S$. lividans RM3 were grown in a medium supplemented with [U-14 C]chloramphenicol. Of the total radioactivity administered, $19 \%$ became associated with the mycelium; less than half of this was recovered by acetone extraction and examination of the extract by TLC and scanning for radioactivity showed the label to be distributed among numerous unidentified components. The combined ethyl acetate extracts of the culture supernatant accounted for a further $20 \%$ of the radioactivity initially added; the remainder was associated with non-extractable metabolites in the culture supernatant fraction.

When an extract from the culture supernatant at pH 7.3 was fractionated by TLC and scanned for radioactivity, two radioactive metabolites were detected. These were identified by co-crystallization with authentic material to constant specific activity as p-nitrobenzyl alcohol and $N$-acetyl-p-nitrophenylserinol (Fig. 4). Examination by TLC of the metabolites extracted at $\mathrm{pH}$ 2.5 gave a radioactive peak that co-migrated with $p$-nitrobenzoic acid. The amount of radioactivity eluted from the zone was too small to allow further characterization.

\section{Chloramphenicol metabolism by S. lividans $M 252$}

Examination by TLC of ethyl acetate extracts from cultures of $S$. lividans M252 that had been supplemented after $24 \mathrm{~h}$ growth with a sublethal concentration $\left(2 \mu \mathrm{g} \mathrm{ml}^{-1}\right)$ of chloramphenicol showed that the antibiotic was slowly metabolized. The main product was an aromatic compound with an $\boldsymbol{R}_{F}$ value matching that of 1,3-diacetoxychloramphenicol (Fig. 4). The same metabolite was formed in the more drug-tolerant parent strain, S. lividans 1326, when chloramphenicol was added to cultures at $15 \mu \mathrm{g} \mathrm{ml}^{-1}$. The substance isolated from these cultures was confirmed from its spectroscopic properties to be 1,3-diacetoxychloramphenicol.

\section{Metabolism of p-nitrophenylserinol by $S$. lividans}

$N$-Acetyl-p-nitrophenylserinol and $p$-nitrophenylserinol added to $24 \mathrm{~h}$ cultures of $S$. lividans RM3 at concentrations of 100 and $200 \mu \mathrm{g} \mathrm{ml}^{-1}$, respectively, did not affect the subsequent growth of the organism. In contrast, growth of $S$. lividans M252 was inhibited by these concentrations, and in the case of the acetyl derivative, by as little as $20 \mu \mathrm{g} \mathrm{ml}^{-1}$. When added at $15 \mu \mathrm{g} \mathrm{ml}^{-1}$, $p$-nitrophenylserinol was metabolized in cultures of $S$. lividans M252 to substances that were isolated and identified spectroscopically as $N$-acetyl-p-nitrophenylserinol and $p$-nitrobenzyl alcohol.

In cultures of $S$. lividans RM3 to which $190 \mu \mathrm{g}$ p-nitrophenyl[hydroxymethylene- $\left.{ }^{14} \mathrm{C}\right]$ serinol $\mathrm{ml}^{-1}$ was added at inoculation, only $14 \%$ of the radioactivity in the culture $24 \mathrm{~h}$ later was in the non-acidic ethyl acetate extract. TLC of this fraction and scanning for radioactivity showed that the ${ }^{14} \mathrm{C}$ was present in only one 


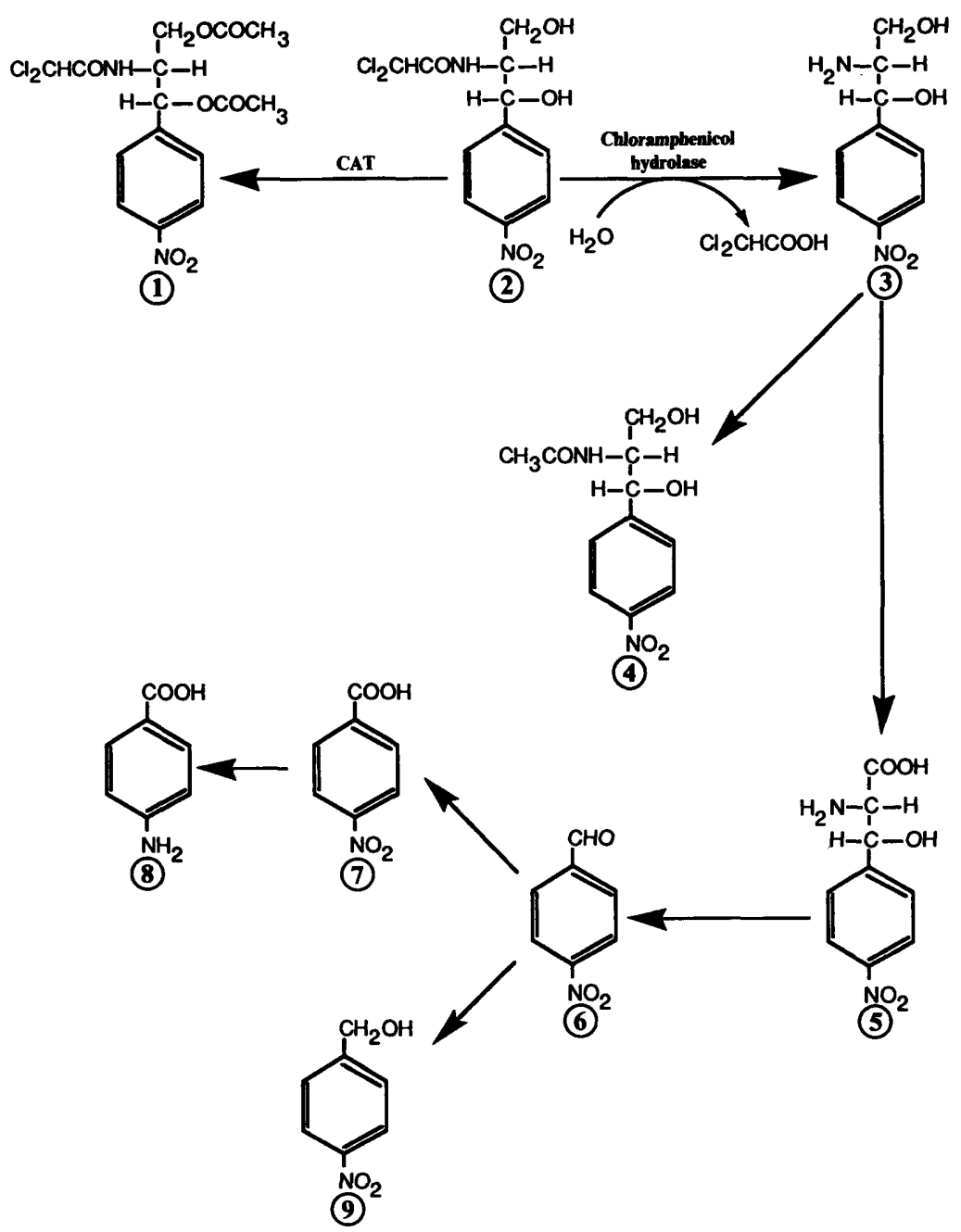

Fig. 4. Pathways by which chloramphenicol (compound 2) is inactivated: formation of 1,3-diacetoxychloramphenicol (1), catalysed by chloramphenicol acetyltransferase (CAT), was found in S. lividans 1326 and M252; the route via p-nitrophenylserinol (3), catalysed by chloramphenicol hydrolase, is postulated to occur in $S$. venezuelae and in $S$. lividans RM3 which accumulate $N$-acetyl-pnitrophenylserinol (4), p-nitrobenzoic acid (7) and p-nitrobenzyl alcohol (9). $p$-Nitrophenylserine (5) and p-nitrobenzaldehyde (6) have been identified in $S$. venezuelae and $p$-aminobenzoic acid (8) has been isolated from $S$. lividans RM3 (N. P. Ranade, unpublished).

metabolite, the $\boldsymbol{R}_{F}$ of which (0.34) coincided with that of $N$-acetyl-p-nitrophenylserinol. An unlabelled product at $R_{F} \mathbf{0} \cdot 72$ co-chromatographed with $p$-nitrobenzyl alcohol but no unmetabolized $p$-nitrophenylserinol could be detected. $N$-Acetyl-p-nitrophenylserinol and $p$-nitrobenzyl alcohol were isolated and identified spectroscopically as above.

\section{Discussion}

Since a $5.2 \mathrm{~kb}$ segment lying between a $K p n I$ site in the vector and the single $K p n I$ site in the $6.5 \mathrm{~kb}$ DNA insert in pJV 3 could be removed without altering the chloramphenicol-resistance phenotype conferred by the plasmid, the $\mathrm{cml}$ determinant is present on the remaining $2.4 \mathrm{~kb}$ of insert DNA. Besides the deleted $4.1 \mathrm{~kb}$ portion of the original insert, pJV4 also lacks a $1.1 \mathrm{~kb} K p n \mathrm{I}-S s t \mathrm{I}$ fragment of the pIJ702 vector. The latter DNA encodes all of the upstream portions of the melCl gene (Lee et al., 1988). Thus the possibility that the $\mathrm{cm}^{\mathrm{r}}$ determinant in pJV3 might be expressed from melCl promoter sequences is absent for pJV4. Although the opportunity for read-through from an upstream plasmid promoter remains, the results suggest that the $2.4 \mathrm{~kb}$ insert in pJV4 contains a promoter for $\mathrm{cml}$.

The absence of increased chloramphenicol resistance when the $6.5 \mathrm{~kb}$ insert from pJV3 was introduced into the polylinker site of pTZ18R and, in both orientations with respect to the upstream lac promoter, subcloned in 
E. coli $\mathrm{TG1}$, is probably due to the resistance gene not being expressed. In cultures of the $E$. coli transformants, sublethal chloramphenicol supplements remained unchanged and the products expected from their metabolism could not be detected. The lack of expression from the lac promoter in the vector is presumably due to an inappropriate reading frame or the presence of an intervening termination sequence. Absence of expression from the indigenous $\mathrm{cm} l^{\mathrm{r}}$ promoter is consistent with the observation (Bibb et al., 1985) that many Streptomyces promoters are not recognized by the DNA transcribing system in $E$. coli.

Cultures of $S$. lividans RM3 metabolized [U-14 C]chloramphenicol to radioactive $N$-acetyl-p-nitrophenylserinol and $p$-nitrobenzyl alcohol. A small amount of a substance chromatographically similar to $p$-nitrobenzoic acid was detected as well but could not be conclusively identified. The absence of $p$-nitrophenylserinol is explained by the rapid conversion of this compound to $N$-acetyl-pnitrophenylserinol, demonstrated by supplementing cultures with $p$-nitrophenyl[hydroxymethylene- $\left.{ }^{14} \mathrm{C}\right]$ serinol. The p-nitrobenzyl alcohol also accumulated in these cultures was unlabelled, as anticipated from the location of the label in the supplement. In $S$. venezuelae $13 \mathrm{~s}$, labelled $p$-nitrophenylserinol as well as $p$-nitrobenzoic acid have been identified in cultures after the addition of [U-14C]chloramphenicol (Malik \& Vining, 1970) but the products found were otherwise identical to those found in $S$. lividans RM3. The difference in amounts of $p$ nitrobenzoic acid may be due to a more active reduction of this compound to $p$-aminobenzoic acid demonstrated in S. lividans (N. P. Ranade, unpublished). The overall results suggest that the antibiotic is inactivated by a similar pathway in the two organisms (Fig. 4).

No conversion of chloramphenicol to these products could be detected in $S$. lividans strains not transformed with pJV3 or pJV4. Instead, S. lividans 1326 and M252 modified the antibiotic by $O$-acetylation. The inferred presence of CAT activity supports observations of weak CAT activity in strains M252 (Gil \& Hopwood, 1985) and 1326 (W. Dittrich \& H. Schrempf, unpublished), and would seem to conflict with earlier reports of its absence from strain 1326 (Shaw \& Hopwood, 1976; Gil $\&$ Hopwood, 1985). However, $O$-acetylation of chloramphenicol by this strain depends on the composition of the growth medium and the age of cultures (N. P. Ranade, unpublished) and it is possible that CAT activity is catabolite-repressed under some conditions. The results suggest that $S$. lividans strains M252 and 1326 tolerate chloramphenicol at concentrations up to $6 \mu \mathrm{g} \mathrm{ml}^{-1}$ and $20 \mu \mathrm{g} \mathrm{ml}^{-1}$, respectively, because of inactivation of the antibiotic mediated by CAT. Consistent with this, and with the absence of chloramphenicol hydrolase activity in these strains, is the absence of hybridization between the $6.5 \mathrm{~kb}$ DNA insert of pJV3 and genomic DNA from S. lividans M252 and JG10 (a pab mutant of strain 1326 which exhibits wild-type resistance to chloramphenicol). Whether chloramphenicol resistance in 1326 is due primarily to CAT activity is nevertheless uncertain since W. Dittrich \& H. Schrempf (unpublished) did not observe increased activity in cell extracts from hyperresistant derivatives of this strain.

The absence of chloramphenicol degradation products in S. lividans M252 and their formation in $S$. lividans RM3 suggests that the resident $S$. venezuelae DNA of pJV3 confers resistance to the antibiotic by inactivation. The presence of metabolites derived from $p$-nitrophenylserinol and devoid of the dichloroacetyl substituent of chloramphenicol implicates chloramphenicol hydrolase (Malik \& Vining, 1971) as the initial enzyme catalysing the reactions. Since $S$. lividans M252 metabolized $p$-nitrophenylserinol (but not chloramphenicol) to $N$-acetyl-p-nitrophenylserinol and $p$-nitrobenzyl alcohol, introduction of the DNA coding for chloramphenicol hydrolase from $S$. venezuelae would be sufficient to enable this strain to generate the range of metabolic products observed. Removal from pJV3 of a $4.1 \mathrm{~kb}$ segment of the DNA insert without affecting the chloramphenicol resistance phenotype conferred on $S$. lividans M252 by the plasmid is consistent with the assumption that the cloned fragment contains only the determinant for chloramphenicol hydrolase. Of potential interest is the observation that $N$-acetyl-p-nitrophenylserinol exhibits antibiotic activity (Suzuki et al., 1972). Accumulation of this product, especially in the absence of competing degradative reactions, might cause growth inhibition and mask phenotypic expression of resistance.

The results of the Southern hybridization experiment indicated that the $6.5 \mathrm{~kb}$ fragment from $S$. venezuelae ISP5230 had strong sequence similarity to a comparably sized DNA fragment from $S$. venezuelae $13 \mathrm{~s}$. The $8 \mathrm{~kb}$ hybridizing fragment in the $S$. venezuelae ISP5230 digest is probably due to incomplete digestion. Because $S$. phaeochromogenes NRRLB 3559, like $S$. venezuelae ISP5230 and 13s, produces chloramphenicol (Doull et al., 1983), the lack of hybridization between the probe and its genomic DNA was surprising. It may be that $S$. phaeochromogenes possesses a chloramphenicol hydrolase gene with sufficient sequence similarity to be detected under less stringent conditions for hybridization and washing than those used, which were relatively severe. It is also possible that an $S$. phaeochromogenes gene possesses numerous $S s t \mathrm{I}$ sites and was digested into small fragments not recognized in the hybridization. However, it is not known for certain whether the mechanism by which $S$. phaeochromogenes acquires resistance to its own antibiotic is of the same type as in S. venezuelae. 
This research was supported by the Natural Sciences and Engineering Research Council of Canada. We thank C. Stuttard, J. L. Doull, J. M. Wright, D. A. Aidoo, D. A. Hopwood, J. A. Gil and E. Katz for gifts of cultures. We also thank J. A. Walter, Atlantic Research Laboratory, National Research Council of Canada, for the nuclear magnetic resonance spectra.

\section{References}

Ahmed, Z. U. \& Vining, L. C. (1983). Evidence for a chromosomal location of the genes coding for chloramphenicol production in Streptomyces venezuelae. Journal of Bacteriology 154, 239-244.

Betzler, M., Dyson, P. \& SchrempF, H. (1987). Relationship of an unstable $\arg G$ gene to a $5 \cdot 7-\mathrm{kb}$ amplifiable DNA sequence in Streptomyces lividans 66. Journal of Bacteriology 169, 4804-4810.

BibB, M. J., BibB, M. J., Ward, J. M.. \& CoheN, S. N. (1985). Nucleotide sequences encoding and promoting expression of three antibiotic resistance genes indigenous to Streptomyces. Molecular and General Genetics 199, 26-36.

Carter, P., Bedouelle, H. \& Winter, G. (1985). Improved oligonucleotide site-directed mutagenesis using M13 vectors. Nucleic Acids Research 13, 4431-4443.

Doull, J. L., Vining, L. C. \& StUtTaRd, C. (1983). A cryptic plasmid in the chloramphenicol-producing actinomycete, Streptomyces phaeochromogenes. FEMS Microbiology Letters 16, 349-352.

Doull, J., AHMEd, Z., StutTARD, C. \& Vining, L. C. (1985). Isolation and characterization of Streptomyces venezuelae mutants blocked in chloramphenicol biosynthesis. Journal of General Microbiology 131, 97-104.

GIL, J. A. \& Hopwood, D. A. (1983). Cloning and expression of a paminobenzoic acid synthetase gene of the candicidin-producing Streptomyces griseus. Gene 25, 119-132.

GiL, J. A., Kieser, H. M. \& Hopwood, D. A. (1985). Cloning of a chloramphenicol acetyltransferase gene of Streptomyces acrimycini and its expression in Streptomyces and Escherichia coli. Gene 38, 1-8.

HopwOoD, D. A. (1967). Genetic analysis and genome structure in Streptomyces coelicolor. Bacteriological Reviews 31, 373-403.

Hopwood, D. A., Bibb, M. J., Chater, K. F., Kieser, T., Bruton, C. J., Kieser, H. M., Lydiate, D. J., SMith, C. P., WARD, J. M. \& SCHREMPF, H. (1985). Genetic Manipulation of Streptomyces: a Laboratory Manual. Norwich: John Innes Foundation.

Katz, E., Thompson, C. J. \& Hopwood, D. A. (1983). Cloning and expression of the tyrosinase gene from Streptomyces antibioticus in Streptomyces lividans. Journal of General Microbiology 129, 27032714.
KIESER, T. (1984). Factors affecting the isolation of ccc DNA from Streptomyces lividans and Escherichia coli. Plasmid 12, 19-36.

LEE, Y.-H.W., ChEN, B.-F., WU, S.-Y., LEU, W.-M., LIN, J.-J., ChEN, C. W. \& Lo, S. J. (1988). A trans-acting gene is required for phenotypic expression of a tyrosinase gene in Streptomyces. Gene 65, 71-81.

MaLIK, V. S. \& VINING, L. C. (1970). Metabolism of chloramphenicol by the producing organism. Canadian Journal of Microbiology 16, 173-179.

MaLIK, V. S. \& VINING, L. C. (1971). Metabolism of chloramphenicol by the producing organism. Some properties of chloramphenicol hydrolase. Canadian Journal of Microbiology 17, 1287-1290.

MaLIK, V. S. \& VINING, L. C. (1972). Chloramphenicol resistance in a chloramphenicol-producing Streptomyces. Canadian Journal of Microbiology 18, 583-590.

MEAD, D. A. \& KEMPER, B. (1988). Chimeric single-stranded DNA phage-plasmid cloning vectors. In Vectors, pp. 85-102. Edited by R. L. Rodriguez \& D. T. Denhardt. Toronto: Butterworths.

Pongs, O. (1979). Chloramphenicol. In Antibiotics, vol. 5, part I, Mechanism of Action of Antibacterial Agents, pp. 26-42. Edited by F. E. Hahn. New York: Springer Verlag.

Rebstock, M. C., Crooks, H. M. JR., Controulis, I. \& Bartz, W. R. (1949). Chloramphenicol (chloromycetin). IV. Chemical studies. Journal of the American Chemical Society 71, 2458-2462.

Schottel, J. L., Bibb, M. J. \& CoheN, S. N. (1981). Cloning and expression in Streptomyces lividans of antibiotic resistance genes derived from Escherichia coli. Journal of Bacteriology 146, 360-368.

SCHREMPF, H. (1982). Plasmid loss and changes within the chromosomal DNA of Streptomyces reticuli. Journal of Bacteriology 151, 701707.

SHAW, W. V. (1975). Chloramphenicol acetyltransferase from chloramphenicol-resistant bacteria. Methods in Enzymology 43, 737-755.

SHAw, W. V. \& HOPWOOD, D. A. (1976). Chloramphenicol acetylation in Streptomyces. Journal of General Microbiology 94, 159-166.

STUTTARD, C. (1982). Temperate phages of Streptomyces venezuelae: lysogeny and host specificity shown by phages SV1 and SV2. Journal of General Microbiology 128, 115-121.

Suzuki, T., Honda, H. \& Katsumata, R. (1972). Production of antibacterial compounds analogous to chloramphenicol by a $n$ paraffin-grown bacterium. Agricultural and Biological Chemistry 36, 2223-2228.

ThOMPSON, C. J., WARD, J. M. \& HoPwoOd, D. A. (1982). Cloning of antibiotic resistance and nutritional genes in streptomycetes. Journal of Bacteriology 151, 668-677.

VINING, L. C. (1975). Chloramphenicol hydrolase. Methods in Enzymology 43, 734-737.

Vining, L. C. \& Westlake, D. W. S. (1984). Chloramphenicol: properties, biosynthesis, and fermentation. In Biotechnology of Industrial Antibiotics. pp. 387-411. Edited by E. J. Vandamme. New York: Marcel Dekker. 